\title{
Dinitrosylmolybdenum Complexes with Anion Ligands Coordinating by Oxygen Atoms. Synthesis, Electronic Structure and Olefin Metathesis Activity of Carboxylato-Dinitrosyl-Molybdenum Complexes
}

\author{
Antoni Keller* and Ludmiła Szterenberg \\ Institute of Chemistry, University of Wrocław, Joliot-Curie 14, 50-383 Wrocław, Poland \\ Z. Naturforsch. 47b, 1469-1476 (1992); received December 13, 1991 \\ Dinitrosylmolybdenum Complexes, Carboxylato Complexes, \\ Electronic Structure Calculation, Spectroscopic Properties, Olefin Metathesis \\ The new carboxylato-dinitrosyl-molybdenum complexes of the formula: \\ $\left[\mathrm{Mo}(\mathrm{NO})_{2}\left(\mathrm{O}_{2} \mathrm{CMe}\right)_{2}\right] \cdot \mathrm{MeOH}, \mathrm{Na}_{2}\left[\mathrm{Mo}(\mathrm{NO})_{2}\left(\mathrm{O}_{2} \mathrm{CMe}\right)_{4}\right]$ and $\mathrm{Mo}(\mathrm{NO})_{2}\left(\mathrm{O}_{2} \mathrm{CPh}\right)_{2}$ have been \\ synthesized. Their structure was resolved on the basis of spectroscopic investigations $\left({ }^{1} \mathrm{H}\right.$ \\ NMR, IR, UV-VIS). Catalytic activity of these complexes in olefin metathesis reaction was \\ also examined. \\ The electronic structure of dinitrosyl-molybdenum complexes with ligands coordinating by \\ oxygen atoms was calculated for the example of the di- and tetra-acetato-dinitrosyl-molybden- \\ um complexes using the Fenske-Hall and INDO methods. To interpret the spectroscopic \\ properties (UV-VIS) within the method of interaction configuration, the electronic structure \\ of the excited states was calculated.
}

\section{Introduction}

Since many years transition metal nitrosyl complexes are the subject of intensive studies. Their crystal and molecular structures have been determined and their magnetic, spectroscopic and chemical properties investigated [1-4]. The interest in these compounds continues to grow because there now is a considerable number of complexes available, which could be catalysts or catalysts precursors of many organic reactions such as oligomerization [5-7], polymerization [7-8], chemical oxidation $[9,10]$, hydrogenation [11], isomerization [12,13] and metathesis [14]. For the latter, the molybdenum complexes belong to the most active.

Basset et al. [15] have found that oxygen containing compounds $\left(\mathrm{O}_{2}\right.$ or alcohols $)$ accelerate the metathesis reaction. It has also been proved, that oxygen and perhaps chlorine are essential for generation of active, table high-valent metathesis catalysts [16]. The results of an ab initio theoretical mechanistic study [17] were also used to suggest that oxygen-alkylidene complexes are the active chain-carrying metathesis catalysts for high-valent metal complexes, and that the oxygen ligand is in-

\footnotetext{
* Reprint requests to Dr. A. Keller.

Verlag der Zeitschrift für Naturforschung,

D-W-7400 Tübingen

0932-0776/92/1000-1469/\$01.00/0
}

timately involved in the catalytic process. Moreover the synthesis of stable alkylidene complexes with oxygen ligands, very often active in olefin metathesis, points to the unusual role of ligands of that type as stabilizers and activators $[18,19]$. The first synthetized stable and catalytically active alkylidene-dinitrosyl-molybdenum complexes also contain ligands with oxygen atoms [20,21], and the $\left\{\mathrm{Mo}(\mathrm{NO})_{2}(\mathrm{OMe})_{2} \mathrm{~L}\right\}_{n}-\mathrm{EtAlCl}{ }_{2}$ and

$\left\{\mathrm{Mo}(\mathrm{NO})_{2}\left(\mathrm{O}_{2} \mathrm{CMe}\right)_{2}\right\}_{n}-\mathrm{EtAlCl}_{2}$ systems are some of the most powerful catalysts [22, 23].

Here the synthesis, spectroscopic characterization, electronic structure and metathesis activity of new carboxylato-dinitrosyl-molybdenum complexes are reported. The electronic structure of these complexes was calculated using Fenske-Hall and INDO methods. Their electronic spectra were interpreted in terms of the electronic structure of the excited states calculated by the interaction configuration method.

\section{Experimental}

All experiments were performed under argon atmosphere with standard Schlenk techniques and vacuum-line procedure. Solvents were purified and distilled under argon from appropriate agents. The complexes $\left[\mathrm{Mo}(\mathrm{NO})_{2}\left(\mathrm{MeNO}_{2}\right)_{4}\right]\left(\mathrm{BF}_{4}\right)_{2}$ [24], $\left\{\mathrm{Mo}(\mathrm{NO})_{2}\left(\mathrm{O}^{i} \mathrm{Pr}\right)_{2}\right\}_{n}, \quad\left\{\mathrm{Mo}(\mathrm{NO})_{2}(\mathrm{OR})_{2} \mathrm{~S}\right\}_{n}(\mathrm{R}=$ $\mathrm{Me}, \mathrm{S}=\mathrm{MeCN} ; \mathrm{R}=\mathrm{Et}, \mathrm{S}=\mathrm{EtOH})[25]$ and $\left\{\mathrm{Mo}(\mathrm{NO})_{2}\left(\mathrm{O}_{2} \mathrm{CMe}\right)_{2}\right\}_{n}[23]$ were prepared by published procedure. 
The IR spectra were measured on a Specord M 80 spectrophotometer in hexachlorobutadiene and Nujol mulls. ${ }^{1} \mathrm{H}$ NMR spectra were recorded on a Tesla BS567A spectrometer and were referenced to $\mathrm{Me}_{4} \mathrm{Si}$. Electronic spectra (absorption and reflectance) were measured on a Beckman UV 5240 spectrophotometer. Molecular weights were determined on a Perkin-Elmer 115 instrument. GLC analysis were performed on N-504 (Elpo) chromatograph.

\section{$\left[\mathrm{Mo}(\mathrm{NO})_{2}\left(\mathrm{O}_{2} \mathrm{CMe}\right)_{2}\right] \cdot \mathrm{MeOH}$}

Method A. The mixture of $\mathrm{Mo}(\mathrm{CO})_{6}(4 \mathrm{mmol})$, $\mathrm{Na}\left(\mathrm{O}_{2} \mathrm{CMe}\right)(8 \mathrm{mmol})$ and $\mathrm{NOBF}_{4}(8.2 \mathrm{mmol})$ in $15 \mathrm{ml} \mathrm{MeNO} \mathrm{M}_{2}$ were stirred for $2 \mathrm{~h}$ at room temperature and next $6 \mathrm{ml} \mathrm{MeOH}$ was added. The white precipitate of $\mathrm{NaBF}_{4}$ was filtered off and the solvent was removed from the filtrate in vacuo. The complex was extracted from the residue with $\mathrm{CH}_{2} \mathrm{Cl}_{2}$. The light-green complex was precipitated with hexane. Yield $35 \%$.

Method B. To $\left[\mathrm{Mo}(\mathrm{NO})_{2}\left(\mathrm{MeNO}_{2}\right)_{4}\right]\left(\mathrm{BF}_{4}\right)_{2}$ ( $4 \mathrm{mmol}$ ) dissolved in $15 \mathrm{ml} \mathrm{MeNO}_{2}$ and $6 \mathrm{ml}$ $\mathrm{MeOH} \mathrm{Na}\left(\mathrm{O}_{2} \mathrm{CMe}\right)(8 \mathrm{mmol})$ was added. The white precipitate of $\mathrm{NaBF}_{4}$ was filtered off. Subsequent procedure was as above.

$\left[\mathrm{C}_{5} \mathrm{H}_{10} \mathrm{~N}_{2} \mathrm{Mo}\right]$

Calcd C 19.62 H 3.29 N 9.15 Mo 31.34\%, Found C 19.21 H 3.52 N 8.90 Mo 31.25\%.

IR: $v(\mathrm{OH}) 3400 \mathrm{br}, v(\mathrm{CH}) 2950 \mathrm{sh}, 2917 \mathrm{w}$, $v_{\mathrm{s}}(\mathrm{NO}) 1770 \mathrm{vs}, v_{\mathrm{as}}(\mathrm{NO}) 1650 \mathrm{vs}, v_{\mathrm{as}}\left(\mathrm{CO}_{2}\right) 1520 \mathrm{~s}$, $v_{\mathrm{s}}\left(\mathrm{CO}_{2}\right)+\delta\left(\mathrm{CH}_{3}\right) 1437 \mathrm{~s}, 1410 \mathrm{~s}$, also: $1300 \mathrm{w}, 1150$ $\mathrm{w}, 1030 \mathrm{~m}, 950 \mathrm{sh}, 835 \mathrm{br}, 688 \mathrm{w}, 672 \mathrm{w}, 651 \mathrm{w}, 618$ vw, $565 \mathrm{~m}, 509 \mathrm{~m}, 477 \mathrm{w}, 425 \mathrm{sh}$.

\section{$\mathrm{Na}_{2}\left[\mathrm{Mo}(\mathrm{NO})_{2}\left(\mathrm{O}_{2} \mathrm{CMe}\right)_{4}\right]$}

To the solution of $\left[\mathrm{Mo}(\mathrm{NO})_{2}\left(\mathrm{MeNO}_{2}\right)_{4}\right]\left(\mathrm{BF}_{4}\right)_{2}$ $(4 \mathrm{mmol})$ in $\left.10 \mathrm{ml} \mathrm{MeNO}_{2} \mathrm{Na}_{(} \mathrm{O}_{2} \mathrm{CMe}\right)$ (16.2 mmol) in $12 \mathrm{MeOH}$ was added. The white $\mathrm{NaBF}_{4}$ precipitate was filtered off. From the filtrate the very fine-crystalline light-green precipitate settled down, which after filtration was washed repeatedly with small amounts of $\mathrm{MeOH}$ and dried in vacuo. Yield $70 \%$.

$\left[\mathrm{C}_{8} \mathrm{H}_{12} \mathrm{~N}_{2} \mathrm{MoNa}_{2}\right]$

Calcd C21.93 H2.76 N6.39 Mo $21.90 \mathrm{Na} 10.49 \%$, Found C21.55 H2.91 N6.09 Mo21.78 Na 10.60\%.

IR: $v(\mathrm{CH}) 2935 \mathrm{vw}, v_{\mathrm{s}}(\mathrm{NO}) 1788 \mathrm{~s}, v_{\mathrm{as}}(\mathrm{NO}) 1652$ vs, br, $v_{\text {as }}\left(\mathrm{CO}_{2}\right) 1596 \mathrm{vs}, \delta\left(\mathrm{CH}_{3}\right) 1440 \mathrm{w}, 1423 \mathrm{w}$, $1396 \mathrm{~m}, 1376 \mathrm{~m}, 1335 \mathrm{w}, v_{\mathrm{s}}\left(\mathrm{CO}_{2}\right) 1300 \mathrm{vs}, \varrho_{\mathrm{r}}\left(\mathrm{CH}_{3}\right)$ $1040 \mathrm{~m}, 1018 \mathrm{~m}, v(\mathrm{CC}) 940 \mathrm{w}, 930 \mathrm{w}$, also: $578 \mathrm{~m}$,
$587 \mathrm{~m}, 570 \mathrm{sh}, 550 \mathrm{vw}, 532 \mathrm{vw}, 529 \mathrm{vw}, 485 \mathrm{~m}, 475$ sh, $438 \mathrm{~m}, 420 \mathrm{sh}$.

$$
\mathrm{Mo}(\mathrm{NO})_{2}\left(\mathrm{O}_{2} \mathrm{CPh}\right)_{2}
$$

To $\left[\mathrm{Mo}(\mathrm{NO})_{2}\left(\mathrm{MeNO}_{2}\right)\right]\left(\mathrm{BF}_{4}\right)_{2}(4 \mathrm{mmol})$ in $10 \mathrm{ml}$ $\mathrm{MeNO}_{2}$ or $\mathrm{MeOH}$ the solution of $\mathrm{Li}\left(\mathrm{O}_{2} \mathrm{CPh}\right)(8$ $\mathrm{mmol})$ in $\mathrm{MeOH}(6 \mathrm{ml})$ was added. The resulting solution was stirred for about $1 \mathrm{~h}$ at room temperature and the solvent removed under vacuum. The complex was extracted from the residue with a small amount of $\mathrm{CH}_{2} \mathrm{Cl}_{2}$. The green complex was precipitated with hexane, filtered off and dried in vacuo. Yield $90 \%$.

$\left[\mathrm{C}_{14} \mathrm{H}_{10} \mathrm{~N}_{2} \mathrm{Mo}\right]$

Calcd C 42.23 H 2.53 N 7.04 Mo $24.09 \%$, Found C 41.90 H 2.80 N 6.74 Mo $24.20 \%$.

IR: $v(\mathrm{CH}) 2960 \mathrm{~m}, 2923 \mathrm{w}, 2895 \mathrm{sh}, v_{\mathrm{s}}(\mathrm{NO}) 1790$ s, $v_{\text {as }}(\mathrm{NO}) 1682 \mathrm{vs}, v_{\text {as }}\left(\mathrm{CO}_{2}\right) 1548 \mathrm{~s}, v_{\mathrm{s}}\left(\mathrm{CO}_{2}\right) 1420$ vs, also: $2035 \mathrm{w}, 1955 \mathrm{w}, 1598 \mathrm{~m}, 1508 \mathrm{~m}, 1492 \mathrm{~m}$, $1450 \mathrm{~s}, 1310 \mathrm{w}, 1250 \mathrm{sh}, 1178 \mathrm{~m}, 1150 \mathrm{sh}, 1126 \mathrm{~m}$, $1092 \mathrm{w}, 1070 \mathrm{~m}, 1040 \mathrm{w}, 1025 \mathrm{~m}, 955 \mathrm{sh}, 873 \mathrm{w}$, $840 \mathrm{~m}, 750 \mathrm{sh}, 675 \mathrm{~m}, 650 \mathrm{w}, 617 \mathrm{~m}, 572 \mathrm{w}, 472 \mathrm{~m}$, $425 \mathrm{sh}$.

\section{$\left[\mathrm{Mo}(\mathrm{NO})_{2}\left(\mathrm{O}_{2} \mathrm{CPh}\right)_{2}\right] \cdot 2 \mathrm{PhCO}_{2} \mathrm{H}$}

The complex was obtained in a manner similar to that described above, i.e. by treatment of $\left[\mathrm{Mo}(\mathrm{NO})_{2}\left(\mathrm{MeNO}_{2}\right)_{4}\right]\left(\mathrm{BF}_{4}\right)_{2}$ with $\mathrm{Li}\left(\mathrm{O}_{2} \mathrm{CPh}\right)$ in $\mathrm{MeOH}$ at room temperature in molecular ratio $\leq$ $1: 4$.

$\left[\mathrm{C}_{28} \mathrm{H}_{22} \mathrm{~N}_{2} \mathrm{Mo}\right]$

Calcd C 52.35 H 3.45 N 4.36 Mo $14.93 \%$, Found C 52.09 H 3.60 N 4.00 Mo $14.81 \%$.

IR: $v(\mathrm{OH}) 3100 \mathrm{br}, v(\mathrm{CH}) 2960 \mathrm{sh}, 2925 \mathrm{sh}$, $v_{\mathrm{s}}(\mathrm{NO}) 1790 \mathrm{~s}, \quad v_{\mathrm{as}}(\mathrm{NO})+v_{\mathrm{as}}\left(\mathrm{CO}_{2}\right) 1680$ vs, br, $v_{\text {as }}\left(\mathrm{CO}_{2}\right) 1555 \mathrm{~s}, v_{\mathrm{s}}\left(\mathrm{CO}_{2}\right) 1420 \mathrm{vs}$, also: $2077 \mathrm{w}, 2025$ vw, $1960 \mathrm{vw}, 1910 \mathrm{w}, 1598 \mathrm{~s}, 1580 \mathrm{sh}, 1490 \mathrm{~m}, 1323$ s, $1280 \mathrm{~s}, 1178 \mathrm{~m}, 1155 \mathrm{w}, 1125 \mathrm{~m}, 10190 \mathrm{w}, 1070$ m, $1040 \mathrm{w}, 1025 \mathrm{~m}, 998 \mathrm{vw}, 965 \mathrm{~s}, 927 \mathrm{~m}, 875 \mathrm{sh}$, $830 \mathrm{vw}, 800 \mathrm{w}, 775 \mathrm{w}, 680 \mathrm{~m}, 665 \mathrm{~m}, 640 \mathrm{sh}, 615$ vw, 575 sh, $545 \mathrm{w}, 475 \mathrm{w}$, br, $420 \mathrm{sh}$.

\section{Metathesis reaction}

The following general procedure was used. The precatalyst $\left(2.5 \cdot 10^{-4} \mathrm{~mol}\right)$ and $\mathrm{PhCl}(5 \mathrm{ml})$ were placed in the reaction vessel, and cooled to below $0{ }^{\circ} \mathrm{C}$; next $\mathrm{EtAlCl}_{2}$ in $\mathrm{PhCl}$ was added $(\mathrm{Mo}: \mathrm{Al}=$ $1: 6)$. The resulting homogeneous reaction mixture was heated to room temperature and aged for 15 $\min \left(\mathrm{t}_{\mathrm{a}}\right)$. After ageing pent-2-ene as test olefin (Mo: olefin $=1: 400)$ was added to the solution. For the sample taken after reaction time $\left(t_{r}\right)$ the 
reaction was quenched and the metathesis products were subjected to GLC.

\section{Results and Discussion}

Preparation and properties of carboxylato-dinitrosyl-molybdenum complexes

A few examples of dinitrosyl-molybdenum complexes with anion ligands containing oxygen atom have been described in the literature, i.e. $\mathrm{Mo}(\mathrm{NO})_{2}(\mathrm{acac})_{2}[26],\left\{\mathrm{Mo}(\mathrm{NO})_{2}(\mathrm{OR})_{2}\right\}_{n}(\mathrm{R}=\mathrm{Et}$, $\left.{ }^{i} \mathrm{Pr}\right)$ and $\left\{\mathrm{Mo}(\mathrm{NO})_{2}(\mathrm{OR})_{2} \mathrm{~L}\right\}_{n}(\mathrm{R}=\mathrm{Me}, \mathrm{Et} ; \mathrm{L}=$ EtOH) [25, 27], $\left(\mathrm{Et}_{4} \mathrm{~N}\right)_{2}\left[\mathrm{Mo}(\mathrm{NO})_{2}(\mathrm{ox})_{2}\right]$ [28] and $\mathrm{Mo}(\mathrm{NO})_{2}\left(\mathrm{HSO}_{4}\right)_{n}(n=3,4)[29]$.

Almost all these complexes could be obtained by substitution of the coordinated solvent in $\left[\mathrm{Mo}(\mathrm{NO})_{2}(\mathrm{solv})_{4}\right]^{2+}$ type complexes by the appropriate oxygen anion ligands.

Quite recently a new complex of that type was synthetized in the same manner:

$$
\begin{aligned}
& {\left[\mathrm{Mo}(\mathrm{NO})_{2}(\mathrm{MeCN})_{4}\right]\left(\mathrm{BF}_{4}\right)_{2} \underset{2}{\stackrel{2 \mathrm{Na}\left(\mathrm{O}_{2} \mathrm{CMe}\right)}{-2 \mathrm{NaBF}_{4}}}} \\
& \mathrm{Mo}(\mathrm{NO})_{2}\left(\mathrm{O}_{2} \mathrm{CMe}\right)_{2}
\end{aligned}
$$

This compound is also formed in the direct reaction among $\mathrm{Me}(\mathrm{CO})_{6}, \mathrm{Na}\left(\mathrm{O}_{2} \mathrm{CMe}\right)$ and $\mathrm{NOBF}_{4}$ :

$$
\begin{aligned}
& \mathrm{Mo}(\mathrm{CO})_{6} \frac{2 \mathrm{Na}\left(\mathrm{O}_{2} \mathrm{CMe}\right), 2 \mathrm{NOBF}_{4}}{-6 \mathrm{CO},-2 \mathrm{NaBF}_{4}} \\
& \mathrm{Mo}(\mathrm{NO})_{2}\left(\mathrm{O}_{2} \mathrm{CMe}\right)_{2}
\end{aligned}
$$

The mechanism of its formation is the same in both reactions.

Both reactions were carried out in $\mathrm{MeCN}$ at room temperature. The brown product is unsoluble in alkanes, benzene, $\mathrm{PhCl}, \mathrm{CH}_{2} \mathrm{Cl}_{2}$ and $\mathrm{H}_{2} \mathrm{O}$, sparingly soluble in $\mathrm{MeCN}$, and readily soluble in alcohols and DMSO. Its structure is most likely polymeric $\left\{\mathrm{Mo}(\mathrm{NO})_{2}\left(\mathrm{O}_{2} \mathrm{CMe}\right)_{2}\right\}_{n}$.

The complex of the identical composition in the coordination sphere but of different physical properties is formed in the reaction of $\left[\mathrm{Mo}(\mathrm{NO})_{2}\left(\mathrm{MeNO}_{2}\right)_{4}\right]\left(\mathrm{BF}_{4}\right)_{2}$ with $\mathrm{Na}\left(\mathrm{O}_{2} \mathrm{CMe}\right)$ (1:2) in $\mathrm{MeNO}_{2}-\mathrm{MeOH}$ solution (reaction (3)), a light-green compound of the formula
$\left[\mathrm{Mo}(\mathrm{NO})_{2}\left(\mathrm{O}_{2} \mathrm{CMe}\right)_{2}\right] \cdot \mathrm{MeOH}$, insoluble in alkanes and $\mathrm{H}_{2} \mathrm{O}$, soluble in $\mathrm{CH}_{2} \mathrm{Cl}_{2}$, benzene and $\mathrm{PhCl}$. It is a monomer, as indicated by its molecular weight (found 310.10; calcd for $\left[\mathrm{Mo}(\mathrm{NO})_{2}\left(\mathrm{O}_{2} \mathrm{CMe}\right)_{2}\right]$ : 274.04).

The change of the ratio of reagents $\left[\mathrm{Mo}(\mathrm{NO})_{2}\left(\mathrm{MeNO}_{2}\right)_{4}\right]\left(\mathrm{BF}_{4}\right)_{2}$ and $\mathrm{Na}\left(\mathrm{O}_{2} \mathrm{CMe}\right)$ from $1: 2$ to $1: 4$ in $\mathrm{MeNO}_{2}-\mathrm{MeOH}$ solution allows the coordination of two additional acetate groups (reaction (3)).

$\mathrm{Na}_{2}\left[\mathrm{Mo}(\mathrm{NO})_{2}\left(\mathrm{O}_{2} \mathrm{CMe}\right)_{4}\right]$ is a very fine-crystalline green compound, sparingly soluble in $\mathrm{MeOH}$ and $\mathrm{MeCN}$.

Reaction between $\left[\mathrm{Mo}(\mathrm{NO})_{2}\left(\mathrm{O}_{2} \mathrm{CMe}\right)_{4}\right]\left(\mathrm{BF}_{4}\right)$ and $\mathrm{Li}\left(\mathrm{O}_{2} \mathrm{CPh}\right)$ in $\mathrm{MeNO}_{2}-\mathrm{MeOH}$ or $\mathrm{MeOH}$ solution gives rise to the formation of the complex $\mathrm{Mo}(\mathrm{NO})_{2}\left(\mathrm{O}_{2} \mathrm{CPh}\right)_{2}$, readily soluble in $\mathrm{CH}_{2} \mathrm{Cl}_{2}$, $\mathrm{CHCl}_{3}$, benzene, $\mathrm{PhCl}$, alcohols and $\mathrm{MeCN}$. A cryoscopic molecular weight determination suggests the existence of monomeric species (found: 389.40; calcd for $\left.\mathrm{Mo}(\mathrm{NO})_{2}\left(\mathrm{O}_{2} \mathrm{CPh}\right)_{2}: 398.18\right)$

Excess of $\mathrm{Li}\left(\mathrm{O}_{2} \mathrm{CPh}\right)$ causes no changes in the coordination sphere of the complex. In the reaction system where

$\left[\mathrm{Mo}(\mathrm{NO})_{2}(\mathrm{MeNO})_{2}\right]\left(\mathrm{BF}_{4}\right): \mathrm{Li}\left(\mathrm{O}_{2} \mathrm{CPh}\right) \leq 1: 4 \quad$ the complex of the formula

$\left[\mathrm{Mo}(\mathrm{NO})_{2}\left(\mathrm{O}_{2} \mathrm{CPh}\right)_{2}\right] \cdot 2 \mathrm{PhCO}_{2} \mathrm{H}$ is formed. Two molecules of benzoic acid could be removed in vacuo $\left(10^{-3} \mathrm{~mm} \mathrm{Hg}\right)$ at $100{ }^{\circ} \mathrm{C}$.

\section{IR spectra}

The IR spectra of the carboxylato-dinitrosylmolybdenum complexes (see Experimental Section and Fig. 1) showed two $v(\mathrm{NO})$ bands typical for cis-dinitrosyl-molybdenum complexes [30] and bands characteristic for coordinated carboxylate ligands.

The $v(\mathrm{NO})$ and $v\left(\mathrm{CO}_{2}\right)$ frequencies in the IR spectrum of $\left[\mathrm{Mo}(\mathrm{NO})_{2}\left(\mathrm{O}_{2} \mathrm{CMe}\right)_{2}\right] \cdot \mathrm{MeOH}$ are somewhat different from those observed for $\left\{\mathrm{Mo}(\mathrm{NO})_{2}\left(\mathrm{O}_{2} \mathrm{CMe}\right)_{2}\right\}_{n}$ [23] but the $\Delta v\left(\mathrm{CO}_{2}\right)=$ $v_{\mathrm{as}}-v_{\mathrm{S}}$ values are in both cases almost identical (97 and $95 \mathrm{~cm}^{-1}$, respectively).

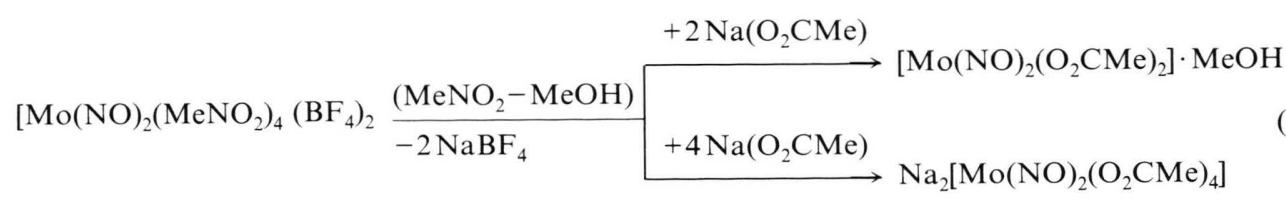




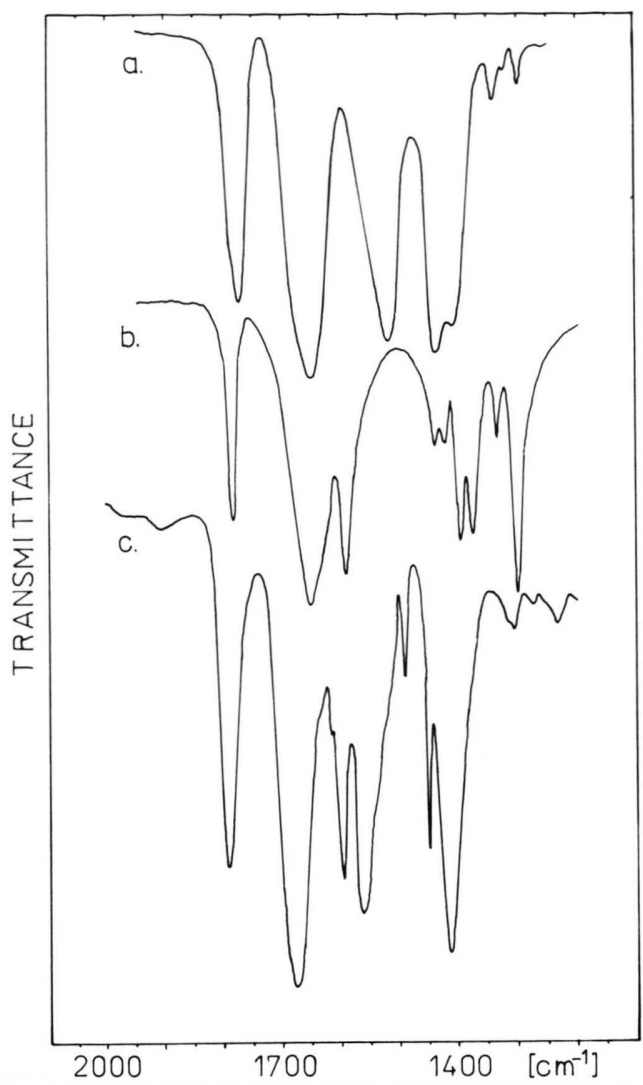

Fig. 1. IR spectra (in $\mathrm{KBr}$ pellet) of

a) $\left[\mathrm{Mo}(\mathrm{NO})_{2}\left(\mathrm{O}_{2} \mathrm{CMe}\right)_{2}\right] \cdot \mathrm{MeOH}$;

b) $\mathrm{Na}_{2}\left[\mathrm{Mo}(\mathrm{NO})_{2}\left(\mathrm{O}_{2} \mathrm{CMe}\right)_{4}\right]$; c) $\mathrm{Mo}(\mathrm{NO})_{2}\left(\mathrm{O}_{2} \mathrm{CPh}\right)_{2}$.

Very low $\Delta v\left(\mathrm{CO}_{2}\right)$ values $\left(<105 \mathrm{~cm}^{-1}\right)$ generally indicate chelation (such as in

$\left.\left[\mathrm{Mo}(\mathrm{NO})_{2}\left(\mathrm{O}_{2} \mathrm{CMe}\right)_{2}\right] \cdot \mathrm{MeOH}\right)$ or a combination of chelation and bridging (most likely in

$\left\{\mathrm{Mo}(\mathrm{NO})_{2}\left(\mathrm{O}_{2} \mathrm{CMe}\right)_{2}\right\}_{n}$ [23]) if short metal-metal bonds are not present [31].

The clearly higher $v_{\text {as }}\left(\mathrm{CO}_{2}\right)$ value in the IR spectrum of $\mathrm{Na}_{2}\left[\mathrm{Mo}(\mathrm{NO})_{2}\left(\mathrm{O}_{2} \mathrm{CMe}\right)_{4}\right]\left(1596 \mathrm{~cm}^{-1}\right.$; Fig. 1) as compared to diacetato-dinitrosyl-molybdenum complexes (about $1520 \mathrm{~cm}^{-1}$ ) and the very high $\Delta v\left(\mathrm{CO}_{2}\right)$ value $\left(296 \mathrm{~cm}^{-1}\right)$ are typical for unidentate acetate groups [31].

The $\Delta v\left(\mathrm{CO}_{2}\right)$ value for the chelate ligands in $\mathrm{Mo}(\mathrm{NO})_{2}\left(\mathrm{O}_{2} \mathrm{CPh}\right)_{2}\left(128 \mathrm{~cm}^{-1}\right)$ exceeds that for the acetate ligands coordinating in a similar way. The IR spectrum of $\left[\mathrm{Mo}(\mathrm{NO})_{2}\left(\mathrm{O}_{2} \mathrm{CPh}\right)_{2}\right] \cdot 2 \mathrm{PhCO}_{2} \mathrm{H}$ displayed $v_{\text {as }}$ and $v_{\mathrm{s}}\left(\mathrm{CO}_{2}\right)$ frequencies characteristic for chelating $\mathrm{PhCO}_{2}{ }^{-}$ligands and non-coordinated benzoic acid molecules.

\section{${ }^{I} H$ NMR spectra}

The ${ }^{1} \mathrm{H}$ NMR spectrum of $\left[\mathrm{Mo}(\mathrm{NO})_{2}\left(\mathrm{O}_{2} \mathrm{CMe}\right)_{2}\right] \cdot \mathrm{MeOH}$ (in $\mathrm{CD}_{2} \mathrm{Cl}_{2}$, at $25^{\circ} \mathrm{C}$ ) exhibits one methyl proton signal of the acetate group $(\delta=2.00 \mathrm{ppm}, \mathrm{s}, 2 \cdot 3 \mathrm{H})$ and proton resonances of methyl alcohol $\left(\delta\left(\mathrm{CH}_{3}\right)=3.38 \mathrm{ppm}\right.$, $\mathrm{s}, 3 \mathrm{H} ; \delta(\mathrm{OH})=4.20 \mathrm{ppm}, \mathrm{s}, 1 \mathrm{H})$.

The ${ }^{1} \mathrm{H}$ NMR spectrum (in $\mathrm{d}_{6}$-DMSO at $25^{\circ} \mathrm{C}$ ) of the polymeric complex $\left\{\mathrm{Mo}(\mathrm{NO})_{2}\left(\mathrm{O}_{2} \mathrm{CMe}\right)_{2}\right\}_{n}$, most likely with chelating and bridging acetates, exhibits also only one methyl proton resonance $(\delta=1.95 \mathrm{ppm})$ [23]. This may be caused by dynamic exchange process between chelating and bridging acetates, or, even more likely, by destruction of the polymeric structure of the compound with possible coordination of the solvent molecules. Since the recorded in $\mathrm{MeOH}$ spectrum in the range $-90{ }^{\circ} \mathrm{C}$ to $+60{ }^{\circ} \mathrm{C}$ the latter suggestion is preferred.

The ${ }^{1} \mathrm{H}$ NMR spectrum of $\mathrm{Na}_{2}\left[\mathrm{Mo}(\mathrm{NO})_{2}\left(\mathrm{O}_{2} \mathrm{CMe}\right)_{4}\right]$ in $\mathrm{CD}_{3} \mathrm{OD}$ exhibits two singlets of equal intensity reflecting the nonequivalence of the ligands coordinated in the trans and cis positions $\left(\delta\left(\mathrm{CH}_{3}\right)=1.97\right.$ and $\left.2.07 \mathrm{ppm}\right)$.

The ${ }^{1} \mathrm{H}$ NMR spectrum of $\mathrm{Mo}(\mathrm{NO})_{2}\left(\mathrm{O}_{2} \mathrm{CPh}\right)_{2}$ in $\mathrm{CD}_{2} \mathrm{Cl}_{2}$ exhibits a multiplet at $7.55 \mathrm{ppm}$ of an intensity corresponding to three protons $(2 \mathrm{H}$ meta and $1 \mathrm{H} \mathrm{para}$ ) and a doublet at $8.07 \mathrm{ppm}$ corresponding to two ortho protons. In the ${ }^{1} \mathrm{H}$ NMR spectrum of $\left[\mathrm{Mo}(\mathrm{NO})_{2}\left(\mathrm{O}_{2} \mathrm{CPh}\right)_{2}\right] \cdot 2 \mathrm{PhCO}_{2} \mathrm{H}$ the signals of the phenyl protons of the attached benzoic acid (7.45 ppm, m, 3 H; $7.96 \mathrm{ppm}, \mathrm{d}, 2 \mathrm{H})$ and the signal of the carboxyl proton $\left(\delta\left(\mathrm{PhCO}_{2} \mathrm{H}\right)=\right.$ $10.45 \mathrm{ppm}, \mathrm{s}, 1 \mathrm{H})$ are observed additionally.

\section{Electronic structure}

The bonding in dinitrosyl-molybdenum complexes and their electronic structure has been discussed quantitatively by Enemark and Feldham [1] as dominated by the $\left\{\mathrm{Mo}(\mathrm{NO})_{2}\right\}^{6}$ unit, in which six electrons are associated with the molybdenum $4 \mathrm{~d}$ and $\pi^{*}(\mathrm{NO})$ orbitals.

In this paragraph the results of theoretical studies on the electronic structure of dinitrosyl molybdenum complexes with oxygen anion ligands, exemplified on the di- and tetraacetato-dinitrosyl molybdenum complexes, are reported.

The calculations were performed by the parameter-free Fenske-Hall [32] and the semiempirical INDO methods [33]. 
In the nearest environment of the central ion of the complexes there are two NO groups in mutual cis position and four carboxyl group oxygen atoms. Two coordination modes of the acetate ions were taken into account: as unidentate ligands in $\left[\mathrm{Mo}(\mathrm{NO})_{2}\left(\mathrm{O}_{2} \mathrm{CMe}\right)_{2}\right]^{2-}$ and as chelating ligands in $\mathrm{Mo}(\mathrm{NO})_{2}\left(\mathrm{O}_{2} \mathrm{CMe}\right)_{2}$. For both complexes a linear coordination of the NO group was assumed, as most frequently observed in complexes of that type $[1,4]$.

The structure of $\mathrm{Mo}(\mathrm{NO})_{2}\left(\mathrm{O}_{2} \mathrm{CMe}\right)_{2}$ was discussed in two geometries: 1) With one $\mathrm{Mo}-\mathrm{O}$ bonding in each chelate ring shorter $(2 \AA)$ than the second one $(2.2 \AA)$, and an elongation of $\mathrm{Mo}-\mathrm{O}$ bonds in the cis position 2) with the $\mathrm{Mo}-\mathrm{O}$ bond lengths identical and equal $2 \AA$. In both cases the acetate group planes form a $90^{\circ}$ angle. The assumed geometries and the systems of coordinates are depicted in Fig. 2. There were two reasons for the choice of such geometries:

1) The linearly coordinated NO ligands show little or no trans influence [4,34].

2) Reactions of complexes of that type with e.g. EtAlCl ${ }_{2}$ suggest, that a free coordination site can easily be reached in trans positions towards NO [22],

3) In $\mathrm{M}_{2}(\mathrm{NO})_{2}(\mathrm{OR})_{6} \mathrm{~L}_{2}(\mathrm{M}=\mathrm{Cr}, \mathrm{Mo}, \mathrm{W})$ complexes the $\mathrm{M}-\mathrm{O}$ bonds in trans positions $v s$. NO are always much longer when compared to the other bonds of that type [35, 36].

The calculated two-center overlap population values and distribution of charges on metal and ligand atoms are listed in Tables I and II. The Wi-

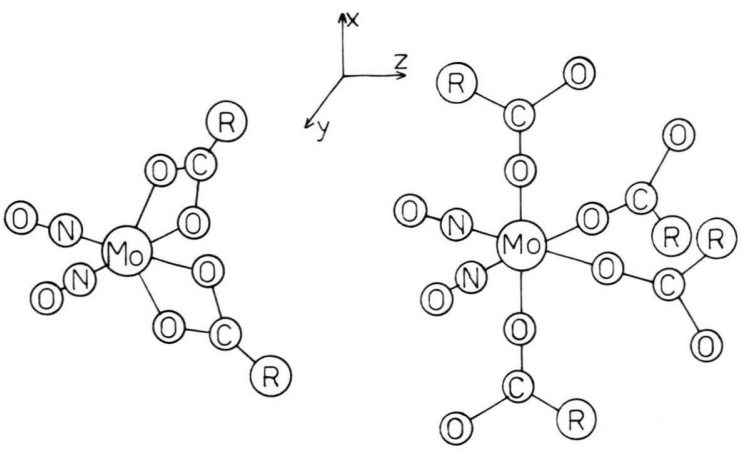

Fig. 2. The geometry of studied complexes.

berg bond indexes [37] calculated by the INDO method are shown in Fig. 3. The molecular orbital schemes are plotted in Fig. 4. Qualitatively identical molecular orbital schemes were obtained for $\mathrm{Mo}(\mathrm{NO})_{2}\left(\mathrm{O}_{2} \mathrm{CMe}\right)_{2}$, with the appropriate $\mathrm{Mo}-\mathrm{O}$ bonds elongated. The results evidently confirm the predominant role of the $\left[\mathrm{Mo}(\mathrm{NO})_{2}\right]^{2+}$ unit, where 6 electrons occupy the delocalized $4 \mathrm{~d}(\mathrm{Mo})$ and $\pi^{*}$ (NO) orbitals. The highest occupied molecular orbitals are $\mathrm{a}\left(\mathrm{d}_{x y} \sim \pi^{*} \mathrm{NO}\right)$ and $\mathrm{b}\left(\mathrm{d}_{x z} \sim \pi^{*} \mathrm{NO}\right)$, and as it was noted previously the difference in their energies is very small $[28,38]$. Both methods produced qualitatively identical sequences of molecular orbitals and similar MO splitting values, but it should be noted that the delocalization of the molecular orbitals in the INDO method is much greater.

\begin{tabular}{lll}
\hline & $\mathrm{Mo}(\mathrm{NO})_{2}\left(\mathrm{O}_{2} \mathrm{CMe}\right)_{2}$ & {$\left[\mathrm{Mo}(\mathrm{NO})_{2}\left(\mathrm{O}_{2} \mathrm{CMe}\right)_{4}\right]^{2-}$} \\
\hline $\mathrm{d} \mathrm{Mo}^{-\mathrm{N}}$ & 0.2750 & 0.2456 \\
$\mathrm{~d} \mathrm{Mo}^{-} \mathrm{O}_{\mathrm{eq}}\left(\mathrm{MeCO}_{2}^{-}\right)$ & 0.0792 & 0.0924 \\
$\mathrm{~d} \mathrm{Mo}^{-} \mathrm{O}_{\mathrm{ax}}\left(\mathrm{MeCO}_{2}^{-}\right)$ & 0.0832 & 0.0899 \\
\hline
\end{tabular}

Table I. Two-center overlap populations for $\mathrm{Mo}(\mathrm{NO})_{2}\left(\mathrm{O}_{2} \mathrm{CMe}\right)_{2}$ and $\left[\mathrm{Mo}(\mathrm{NO})_{2}\left(\mathrm{O}_{2} \mathrm{CMe}\right)_{4}\right]^{2-}$ calculated by Fenske-Hall method.

Table II. Net charges on the molybdenum and ligand atoms.

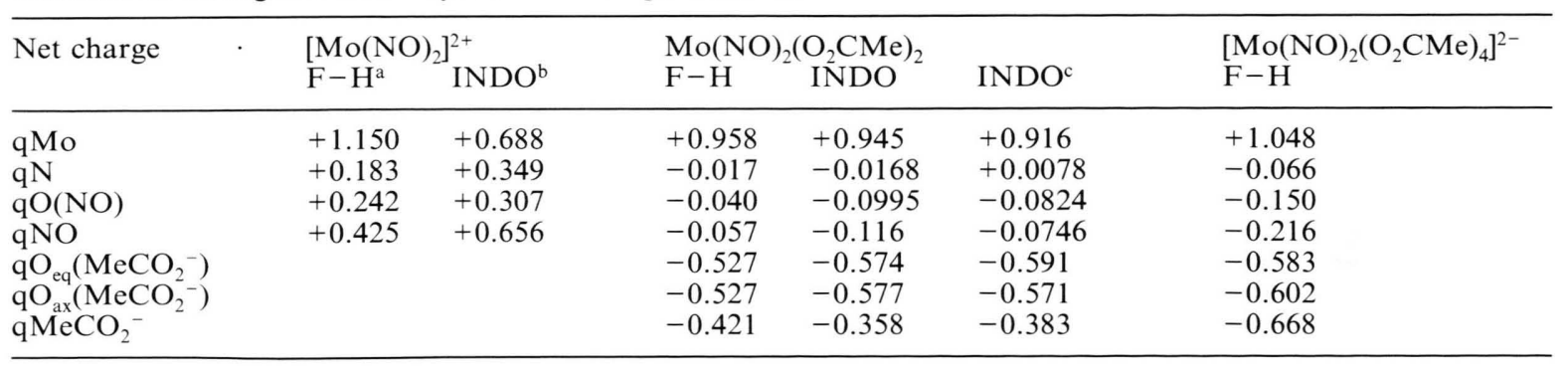

a By Fenske-Hall method; ${ }^{b}$ by INDO method; ${ }^{c}$ the complex with unequal Mo-O bonds. 


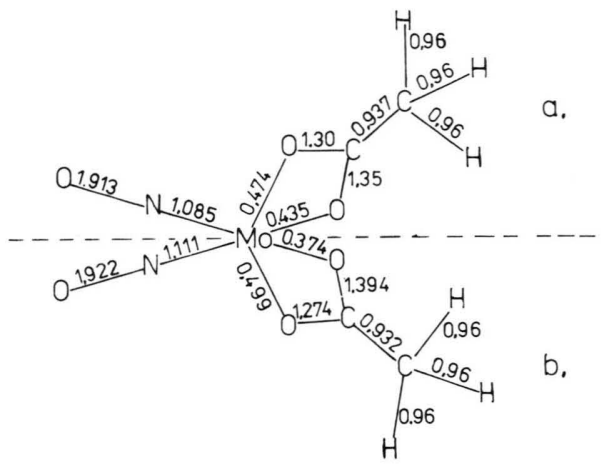

Fig. 3. Wiberg bond indexes: a) for the complex with equivalent $\mathrm{Mo}-\mathrm{O}$ bonds; b) for the complex with nonequivalent $\mathrm{Mo}-\mathrm{O}$ bonds.

a.

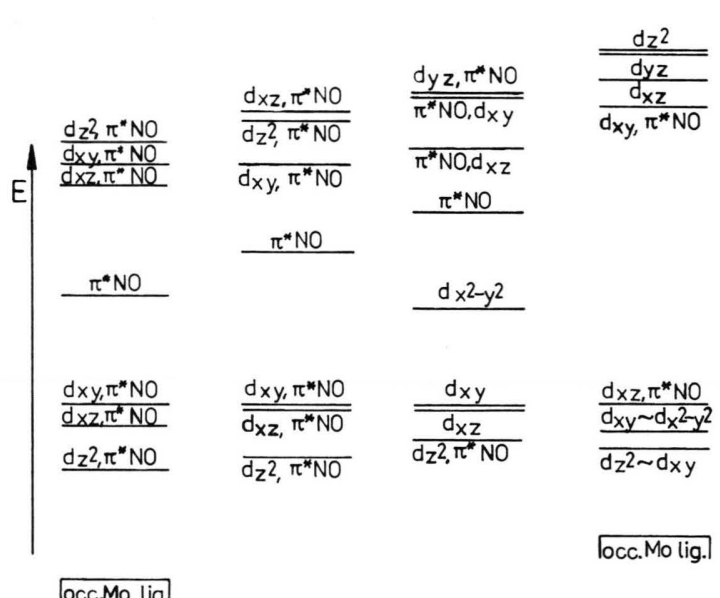

occ.Mo lig.

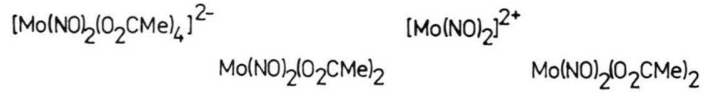

$$
\begin{aligned}
& \text { occ.MoNO }
\end{aligned}
$$

Fig. 4. Molecular orbital diagrams showing the highest filled and lowest unfilled orbitals for the investigated complexes: a, b, c - by Fenske-Hall method; d - by INDO method (for better understanding of the figure the HOMO energies were assigned with the same values).

\section{Electronic spectra}

Electronic spectra (absorption and reflectance) for carboxylato-dinitrosyl-molybdenum and di- alkoxy-dinitrosyl-molybdenum complexes were recorded in the $200-800 \mathrm{~nm}$ region. Table III summarizes the absorption maxima $\left(\lambda_{\max }\right)$ and the molar absorptivity values $(\varepsilon)$, also for the other known dinitrosyl-molybdenum complexes with oxygen anion ligands.

In the case of $\mathrm{Mo}(\mathrm{NO})_{2}\left(\mathrm{O}_{2} \mathrm{CMe}\right)_{2}$ we have tried to explain the spectroscopic properties of dinitrosyl-molybdenum complexes with four ligands coordinating to metal by oxygen atoms. The symmetry of this molecule was approximated to the $\mathrm{C}_{2 \mathrm{v}}$ point group. Equal $\mathrm{Mo}-\mathrm{O}$ bond distances were assumed, since the theoretical calculations revealed no essential changes in the molecular orbitals caused by their differentiation.

The electronic structure of the excited states was calculated by the configuration interaction method [33]. Transition energies and oscillator strengths were determined considering the configurational interaction between the homogeneously excited states. The results of the calculations are confronted with the experimental data in the Table IV. Only the transitions of energies lower than $5.5 \mathrm{eV}$, i.e. those which could have been measured experimentally, where considered. The CT low intensity transitions adjacent to the high intensity ones and the $\mathrm{d}-\mathrm{d}$ transitions located within the intensive CT transition were omitted. The character of transitions was estimated from their contributions to molecular orbitals between which a given transition proceeded.

For the dinitrosyl-molybdenum complexes with four oxygen atoms in the nearest central atom environment, the spectroscopically important molecular orbitals preserve the character of the delocalized orbitals of the $\left[\mathrm{Mo}(\mathrm{NO})_{2}\right]$ moiety. For that reason in the long wavelength region of their spectra (by $5 \mathrm{eV}$ ) one should expect the weak intensity $\mathrm{d}-\mathrm{d}$ and $\mathrm{d} \pi^{*}(\mathrm{NO}) \rightarrow \mathrm{d} \pi^{*}(\mathrm{NO})$ transitions only within this unit (Table IV).

\section{Olefin metathesis reaction}

$\left\{\mathrm{Mo}(\mathrm{NO})_{2}\left(\mathrm{O}_{2} \mathrm{CMe}\right)_{2}\right\}_{n}$ is known to form with EtAlCl ${ }_{2}$ homogeneous, very active catalytic system for metathesis reaction of acyclic [23] and cyclic [27] olefins. $\left[\mathrm{Mo}(\mathrm{NO})_{2}\left(\mathrm{O}_{2} \mathrm{CMe}\right)_{2}\right] \cdot \mathrm{MeOH}$ together with $\mathrm{EtAlCl}_{2}$ displays similar activity. Less active is the system $\mathrm{Na}_{2}\left[\mathrm{Mo}(\mathrm{NO})_{2}\left(\mathrm{O}_{2} \mathrm{CMe}\right)_{4}\right] / \mathrm{EtAl}_{2} \mathrm{Cl}_{2}$, a $50 \%$ conversion of pent-2-ene being achieved 
Table III. Electronic absorption data of dinitrosyl-molybdenum complexes with ligands containing oxygen atoms.

\begin{tabular}{|c|c|c|c|c|c|c|}
\hline \multirow{2}{*}{ Complex } & \multirow[b]{2}{*}{ Solvent } & \multicolumn{2}{|l|}{ Solution } & \multirow[b]{2}{*}{$\varepsilon^{\mathrm{a}}$} & \multicolumn{2}{|l|}{ Solid } \\
\hline & & $\begin{array}{l}\bar{v}_{\max } \\
\left(\mathrm{cm}^{-1}\right)\end{array}$ & $\begin{array}{l}\mathrm{E}_{\max } \\
(\mathrm{eV})\end{array}$ & & $\begin{array}{l}\bar{v}_{\max } \\
\left(\mathrm{cm}^{-1}\right)\end{array}$ & $\begin{array}{l}\mathrm{E}_{\max } \\
(\mathrm{eV})\end{array}$ \\
\hline$\left[\mathrm{Mo}(\mathrm{NO})_{2}\left(\mathrm{O}_{2} \mathrm{CMe}\right)_{2}\right] \cdot \mathrm{MeOH}$ & $\mathrm{CH}_{2} \mathrm{Cl}_{2}$ & $\begin{array}{l}43470 \\
34720 \mathrm{sh} \\
28170 \\
23420 \\
\\
14030\end{array}$ & $\begin{array}{l}5.392 \\
4.306 \\
3.493 \\
2.904 \\
\\
1.740\end{array}$ & $\begin{array}{c}6094 \\
(1020) \\
563 \\
1082 \\
\\
37\end{array}$ & $\begin{array}{l}43500 \\
\\
28570 \\
23400 \\
18350 \mathrm{sh} \\
14250\end{array}$ & $\begin{array}{l}5.393 \\
\\
3.542 \\
2.901 \\
2.275 \mathrm{sh} \\
1.767\end{array}$ \\
\hline$\left\{\mathrm{Mo}(\mathrm{NO})_{2}\left(\mathrm{O}_{2} \mathrm{CMe}\right)_{2}\right\}_{n}$ & $\mathrm{MeOH}$ & $\begin{array}{l}42920 \\
28570 \\
23310 \\
\\
13920\end{array}$ & $\begin{array}{l}5.321 \\
3.542 \\
2.890 \\
1.726\end{array}$ & $\begin{array}{r}6108 \\
388 \\
781 \\
\\
30\end{array}$ & $\begin{array}{l}43350 \\
28600 \\
23500 \\
18190 \mathrm{sh} \\
14560 \mathrm{sh}\end{array}$ & $\begin{array}{l}5.375 \\
3.546 \\
2.914 \\
2.255 \\
1.805\end{array}$ \\
\hline $\mathrm{Na}_{2}\left[\mathrm{Mo}(\mathrm{NO})_{2}\left(\mathrm{O}_{2} \mathrm{CMe}\right)_{4}\right]$ & $\mathrm{H}_{2} \mathrm{O}$ & $\begin{array}{l}43200 \\
34600 \mathrm{sh} \\
28650 \\
23980 \\
14530\end{array}$ & $\begin{array}{l}5.356 \\
4.290 \\
3.552 \\
2.973 \\
1.802\end{array}$ & 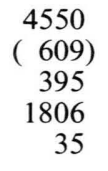 & $\begin{array}{l}43300 \\
\\
28600 \\
23800 \\
14500\end{array}$ & $\begin{array}{l}5.368 \\
\\
3.546 \\
2.951 \\
1.796\end{array}$ \\
\hline $\mathrm{Mo}(\mathrm{NO})_{2}\left(\mathrm{O}_{2} \mathrm{CPh}\right)_{2}$ & $\mathrm{CH}_{2} \mathrm{Cl}_{2}$ & $\begin{array}{l}39520 \mathrm{sh} \\
36360 \mathrm{sh} \\
23420 \\
19050 \mathrm{sh} \\
15380\end{array}$ & $\begin{array}{l}4.900 \\
4.508 \\
2.904 \\
2.362 \\
1.907\end{array}$ & $\begin{array}{c}(4126) \\
(741) \\
1267 \\
\left(\begin{array}{c}154) \\
80\end{array}\right.\end{array}$ & $\begin{array}{l}39520 \\
23450 \\
20000 \mathrm{sh} \\
15350 \mathrm{sh}\end{array}$ & $\begin{array}{l}4.900 \\
\\
2.907 \\
2.480 \\
1.903\end{array}$ \\
\hline$\left\{\mathrm{Mo}(\mathrm{NO})_{2}(\mathrm{OMe})_{2} \mathrm{MeCN}\right\}_{n}$ & $\mathrm{CH}_{3} \mathrm{OH}$ & $\begin{array}{l}43550 \\
28010 \text { sh } \\
23260 \\
13790\end{array}$ & $\begin{array}{l}5.400 \\
3.473 \\
2.884 \\
1.710\end{array}$ & $\begin{array}{c}3830 \\
\left(\begin{array}{c}318) \\
1515 \\
20\end{array}\right.\end{array}$ & & \\
\hline$\left\{\mathrm{Mo}(\mathrm{NO})_{2}(\mathrm{OEt})_{2} \mathrm{EtOH}\right\}_{n}$ & $\mathrm{CH}_{2} \mathrm{Cl}_{2}$ & $\begin{array}{l}42950 \\
29070 \\
23360 \\
13610\end{array}$ & $\begin{array}{l}5.325 \\
3.604 \\
2.896 \\
1.687\end{array}$ & $\begin{array}{r}3300 \\
415 \\
1108 \\
34\end{array}$ & & \\
\hline$\left\{\mathrm{Mo}(\mathrm{NO})_{2}\left(\mathrm{O}^{i} \mathrm{Pr}\right)_{2}\right\}_{n}$ & $\mathrm{CH}_{2} \mathrm{Cl}_{2}$ & $\begin{array}{l}43050 \\
29940 \mathrm{sh} \\
23700 \\
14080\end{array}$ & $\begin{array}{l}5.338 \\
3.712 \\
2.940 \\
1.746\end{array}$ & $\begin{array}{c}3770 \\
(426) \\
1065 \\
39\end{array}$ & & \\
\hline$\left[\mathrm{Et}_{4} \mathrm{~N}\right]\left[\mathrm{Mo}(\mathrm{NO})_{2}(\mathrm{ox})_{2}\right]^{\mathrm{b}}$ & DMF & $\begin{array}{l}23260 \\
12990\end{array}$ & $\begin{array}{l}2.884 \\
1.611\end{array}$ & $\begin{array}{r}1100 \\
50\end{array}$ & & \\
\hline $\mathrm{Mo}(\mathrm{NO})_{2}(\mathrm{acac})_{2}{ }^{\mathrm{b}}$ & DMF & $\begin{array}{l}22470 \\
13610\end{array}$ & $\begin{array}{l}2.786 \\
1.687\end{array}$ & $\begin{array}{r}2100 \\
70\end{array}$ & & \\
\hline
\end{tabular}

a Values of $\varepsilon$ in $\mathrm{dm}^{3} \mathrm{~mol}^{-1} \mathrm{~cm}^{-1}$; ${ }^{\text {b }}$ ref. [28].

Table IV. Calculated and experimental electronic spectra of $\mathrm{Mo}(\mathrm{NO})_{2}\left(\mathrm{O}_{2} \mathrm{CMe}\right)_{2}$.

\begin{tabular}{|c|c|c|c|c|c|}
\hline \multicolumn{2}{|c|}{ Calculated } & \multicolumn{2}{|c|}{ Experimental } & \multirow{2}{*}{ Type of the transition } & \multirow{2}{*}{$\begin{array}{l}\text { Excited } \\
\text { state }\end{array}$} \\
\hline $\begin{array}{l}\mathrm{E} \\
(\mathrm{eV})\end{array}$ & $\mathrm{f}^{\mathrm{a}}$ & $\begin{array}{l}\mathrm{E} \\
(\mathrm{eV})\end{array}$ & $\varepsilon^{\mathrm{b}}$ & & \\
\hline 1.883 & 0.002894 & 1.740 & 37 & 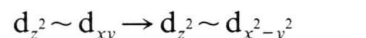 & ${ }^{1} \mathrm{~A}$ \\
\hline 2.283 & 0.000878 & $2.275 \mathrm{sh}^{\mathrm{c}}$ & & $\mathrm{d}_{z^{2}}^{2} \sim \mathrm{d}_{x y}^{x y} \rightarrow \mathrm{d}_{z^{2}}^{z} \sim \mathrm{d}_{x y}^{x-y} \sim \mathrm{d}_{x^{2}-y^{2}}$ & ${ }^{1} \mathrm{~A}$ \\
\hline 2.338 & 0.000750 & & & $\mathrm{~d}_{z^{2}}^{2} \sim \mathrm{d}_{x y}^{x y} \rightarrow \mathrm{d}_{x y}^{z^{-}}$ & ${ }^{1} \mathrm{~B}$ \\
\hline 2.609 & 0.001408 & & & $\mathrm{~d}^{2} \sim \pi^{*} \mathrm{Ny} O \stackrel{x y}{\rightarrow} \mathrm{d} \sim \pi^{*} \mathrm{NO}$ & ${ }^{1} \mathrm{~A}$ \\
\hline 2.733 & 0.045286 & & & $\mathrm{~d} \sim \pi^{*} \mathrm{NO} \rightarrow \mathrm{d} \sim \pi^{*} \mathrm{NO}$ & ${ }^{1} \mathrm{~B}$ \\
\hline 2.935 & 0.050450 & 2.905 & 1082 & $\mathrm{~d} \sim \pi^{*} \mathrm{NO} \rightarrow \mathrm{d} \sim \pi^{*} \mathrm{NO}$ & ${ }^{1} \mathrm{~A}$ \\
\hline 3.221 & 0.012095 & 3.493 & 563 & $\mathrm{~d} \rightarrow \mathrm{d} \sim \pi^{*} \mathrm{NO}$ & ${ }^{1} \mathrm{~B}$ \\
\hline 4.221 & 0.001967 & $4.306 \mathrm{sh}$ & $(1020)$ & $\mathrm{d} \sim \pi^{*} \mathrm{NO} \rightarrow \mathrm{d} \sim \pi^{*} \mathrm{NO}$ & ${ }^{1} \mathrm{~B}$ \\
\hline 5.446 & 0.10887 & 5.392 & 6094 & $\mathrm{pO}_{\mathrm{MeCO}_{-}^{-} \rightarrow \mathrm{d} \sim \pi^{*} \mathrm{NO}}$ & ${ }^{1} \mathrm{~B}$ \\
\hline 5.538 & 0.11116 & & & $\mathrm{~d} \rightarrow \mathrm{d} \sim \sigma \mathrm{C}_{\mathrm{MeCO}_{-}^{-}}^{-}$ & ${ }^{1} \mathrm{~B}$ \\
\hline
\end{tabular}

${ }^{\mathrm{a}}$ Oscillator strength; ${ }^{\mathrm{b}}$ values of $\varepsilon$ in $\mathrm{dm}^{3} \mathrm{~mol}^{-1} \mathrm{~cm}^{-1} ;{ }^{\mathrm{c}}$ reflectance spectra data. 
after $18 \mathrm{~min}$. In all these systems, undoubtedly, the identical carbene catalysts are formed.

$\mathrm{Mo}(\mathrm{NO})_{2}\left(\mathrm{O}_{2} \mathrm{CPh}\right)_{2}$ with EtAlCl$l_{2}$ in chlorobenzene also forms an active catalytic system for olefin metathesis. The metathesis equilibrium of pent2-ene was achieved after $15 \mathrm{~min}$ with the same reaction conditions as above.

Spectroscopic investigations [IR in $v(\mathrm{NO})$ region] of the interactions of the catalyst precursors, i.e. of $\left\{\mathrm{Mo}(\mathrm{NO})_{2}\left(\mathrm{O}_{2} \mathrm{CMe}\right)_{2}\right\}_{n}$ and of the other carboxylato complexes discussed here with $\mathrm{Et} \mathrm{AlCl}_{2}$ allowed to define the carbene catalyst as $\left[\left(\mathrm{AlCl}_{2}\right)_{2}\left(\mathrm{O}_{2} \mathrm{CR}\right)_{2} \mathrm{Mo}(\mathrm{NO})_{2}(\mathrm{CHMe})\right][23,39]$.

The here reported results of the precatalyst electronic structure calculations for particularly char- acteristic bonds (Wibergs bond indexes, Fig. 3), dicenter overlapping population values (Table I), together with charge distribution on central atom and ligand atoms (Table II)) suggest the possibility of formation of such an active catalyst due to the favorable conditions for the electrophilic attack of Lewis acid molecules $\left(\mathrm{Et} \mathrm{AlCl}_{2}\right)$ on carboxylic ligand oxygens in the equatorial plane. The weakest bonds and the highest negative charge concentrations, are associated with the elongated $\mathrm{Mo}-\mathrm{O}$ bonds. In the same plane, i.e. in the $\mathrm{Mo}-\mathrm{NO}$ bonding plane on the side opposite to the NO ligands, the coordination of a carbene ligand requires the smallest amount of activation energy [22].
[1] J. H. Enemark and R. D. Feltham, Coord. Chem. Rev. 13, 339 (1974).

[2] B. Jeżowska-Trzebiatowska, A. Keller, Bull. Acad. Polon. Sci., Ser. Sci. Chim 26, 891 (1978).

[3] A. Keller and B. Jeżowska-Trzebiatowska, Polyhedron 4, 1847 (1985).

[4] R. D. Feltham and J. H. Enemark, in G. L. Geoffroy (ed.): Topics in Inorganic and Organometallic Stereochemistry, Chapter 4, Wiley-Interscience, New York (1981).

[5] J. P. Candlin and W. H. Janes, J. Chem. Soc., C, 1856 (1968).

[6] I. Tkatchenko, J. Organomet. Chem. 124, C 39 (1977).

[7] D. Ballivet, C. Billard, and I. Tkatchenko, ibid. 124, C9 (1977).

[8] A. Sen and R. R. Thomas, Organometallics 1, 1251 (1982).

[9] J. Smidt and R. Jira, Chem. Ber. 93, 162 (1960).

[10] J. Fleischer, D. Schnurpfeil, K. Seyferth, and R. Taube, J. Prakt. Chem. 319, 995 (1977).

[11] C. W. Bird, Transition Metal Intermediates in Organic Synthesis, p. 248, Academic Press, London (1967).

[12] G. Dolcetti, Inorg. Nucl. Chem. Lett. 9, 705 (1973).

[13] C. A. Zuech, W. B. Hughes, D. H. Kubicek, and E. T. Kittleman, J. Am. Chem. Soc. 92, 528 (1970).

[14] K. J. Ivin, Olefin Metathesis, Academic Press, London (1983).

[15] J. M. Basset, G. Coudurier, R. Mutin, H. Proliand, and J. Trambouze, J. Catal. 34, 196 (1974).

[16] M. T. Mocella, R. Rovner, and E. L. Muetterties, J. Am. Chem. Soc. 98, 1689 (1976).

[17] A. K. Rappe and W. A. Goddard III, ibid. 102, 5114 (1980).

[18] R. R. Schrock, S. Rocklage, J. Wengrovious, G. Rupprecht, and J. Fellmann, J. Mol. Catal. 8, 73 (1980).
[19] J. H. Wengrovious, R. R. Schrock, M. R. Churchil, J. R. Missert, and W. J. Youngs, J. Am. Chem. Soc. 102, 4515 (1980).

[20] A. Keller, J. Organomet. Chem. 385, 285 (1990).

[21] A. Keller, ibid. 407, 237 (1991).

[22] A. Keller and L. Szterenberg, J. Mol. Catal. 57, 207 (1989).

[23] A. Keller, ibid. 53, L9 (1989).

[24] P. Lengzdins and J. C. Oxley, Inorg. Chem. 23, 1053 (1984).

[25] A. Keller, Inorg. Chim. Acta 149, 165 (1988).

[26] M. Green and S. H. Taylor, J. Chem. Soc., Dalton. 2629 (1972).

[27] A. Keller, J. Mol. Catal. 64, 171 (1991).

[28] M. Minelli, J. L. Hubbard and J. H. Enemark, Inorg. Chim. 23, 970 (1984) and references therein.

[29] A. Keller, Trans. Met. Chem. 12, 320 (1987).

[30] M. O. Visscher and K. G. Caulton, J. Am. Chem. Soc. 94, 5923 (1972).

[31] G. B. Deacon and R. J. Phillips, Coord. Chem. Rev. 33, 227 (1980).

[32] M. B. Hall and R. F. Fenske, Inorg. Chem. 11, 768 (1972).

[33] N. W. Iwanowa, O. W. Sisowa, and W. I. Baranowski, Zh. Strukt. Khim. 23, 22 (1982).

[34] B. A. Frenz and J. A. Ibers, MTP Int. Rev. Sci. Phys. Chem., Ser 1, 11, 33 (1972).

[35] M. H. Chisholm, F. A. Cotton, M. W. Extine, and L. Kelly, J. Am. Chem. Soc. 100, 3354 (1978).

[36] M. H. Chisholm, J. C. Huffman, and R. L. Kelly, Inorg. Chem. 19, 2762 (1980).

[37] K. A. Wiberg, Tetrahedron 24, 1083 (1968).

[38] B. J. Morris-Sherwood, W. B. S. Kolthammer, and M. B. Hall, Inorg. Chem. 20, 2771 (1981).

[39] A. Keller, to be published. 